\title{
Functional and Biological Properties of Peptides Obtained by Enzymatic Hydrolysis of Whey Proteins ${ }^{1}$
}

\author{
S. F. Gauthier and Y. Pouliot \\ Centre de recherche STELA, Université Laval, \\ Québec, Canada, G1K 7P4
}

\begin{abstract}
The study of peptides released by enzymatic hydrolysis of whey proteins has been initially focusing on improving their functional properties in food model systems. Our first study showed that peptides 41 to 60 and 21 to 40 from $\beta$-lactoglobulin ( $\beta$-LG) were responsible for improved emulsifying properties of a tryptic hydrolysate of whey protein concentrate (WPC). Further work showed that adding negatively charged peptides from tryptic hydrolysates of WPC could prevent phase separation of dairy-based concentrated liquid infant formula, as a replacement for carrageenan. Hydrolysis of whey proteins using a bacterial enzyme was also successful in improving heat stability of whey proteins in an acidic beverage. Some tryptic peptides demonstrated improvement in the heat stability and in modifying thermal aggregation of whey proteins. Recent research has shown that whey peptides could trigger some physiological functions. Within the scope of this research our work has led to the development of a whey protein enzymatic hydrolysate that has demonstrated antihypertensive properties when orally administered to spontaneously hypertensive rats and human subjects. Our work then focused on the fractionation of hydrolysates by nanofiltration to prepare specific peptidic fractions; however, peptide/peptide and peptide/ protein interactions impaired membrane selectivity. The study of those interactions has lead to the demonstration of the occurrence of interactions between $\beta$-LG and its hydrophobic fragment 102-105 (opioid peptide), which probably binds in the central cavity of the protein. This latest result suggests that $\beta$-LG could be used as a carrier for the protection of bioactive peptides from gastric digestion. Our work therefore has shown that the enzymatic hydrolysis of whey proteins is not only
\end{abstract}

\footnotetext{
Received July 31, 2002.

Accepted February 10, 2003.

Corresponding author: Yves Pouliot; e-mail: yves.pouliot@ aln.ulaval.ca.

${ }^{1}$ Presented at the Symposium "Whey Proteins: Structure, Production, Function, and Future" at the ADSA, ASAS Joint Meeting, Quebec, Canada, July 2002.
}

improving their functional properties, but it is also providing powerful technology in the exploitation of their biological properties for functional foods and nutraceutical applications.

(Key words: enzymatic hydrolysate, whey protein, $\beta$ lactoglobulin, whey peptide)

Abbreviation key: $\boldsymbol{\alpha}$-LA $=\alpha$-lactalbumin, $\boldsymbol{\beta}$-LG $=\beta$ lactoglobulin, IEF = isoelectric focusing, $\mathbf{N F}=$ nanofiltration, $\mathbf{U F}=$ ultrafiltration, $\mathbf{W P C}=$ whey protein concentrate, $\mathbf{W P I}=$ whey protein isolate.

\section{INTRODUCTION}

The enzymatic hydrolysis of whey proteins is known to improve some of their functional properties and offers interesting opportunities for food applications. Generally, whey proteins hydrolysates may be expected to have increased solubility, decreased viscosity, and significant changes in foaming, gelling, and emulsifying properties compared to those of native proteins (Chen et al., 1994; Althouse et al., 1995; Huang et al., 1996; Lieske and Konrad, 1996; Singh et Dalgleish, 1998; Rahali and Guéguen, 2000; Euston et al., 2001; van der Ven et al., 2001, 2002). The changes in functional properties of whey proteins are related to peptides produced by enzymatic hydrolysis, which are mainly characterized by a lower molecular weight, exposure of hydrophobic groups, and by an increased number of ionic groups (Panyam and Kilara, 1996). The physiochemical properties of protein hydrolysates are therefore intrinsically related to a number of parameters such as 1) the purity of the protein substrate; 2) the pretreatment of the protein substrate; 3 ) the specificity of the enzyme used for proteolysis; 4) the physicochemical conditions ( $\mathrm{pH}$, temperature, ionic strength, activator) used during hydrolysis; 5) the degree of hydrolysis; 6 ) the technique used for enzyme inactivation (heat treatment, acidification, or membrane filtration); and 7) the use of posthydrolysis treatments (adsorbents for free amino acids, membrane separation).

Our work initially focused on using enzymatic hydrolysis of whey proteins for improving some of their functional properties (Gauthier et al., 1993), but our initial 
findings on the properties of some $\beta$-LG peptides has broadened the scope of our investigation to include more complex food systems, and to the study of some biological properties of whey protein hydrolysates. These new potential applications of whey peptides demonstrated the need for concentrating peptides using nanofiltation (NF) membranes. However, this work revealed the potential occurrence of peptide/ $\beta$-LG and peptide/peptide interactions, which were negatively affecting the selectivity of NF-separation processes. The objective of the present paper is to highlight the potential of whey peptides as food ingredients or nutraceuticals by reviewing key observations made in our work on whey protein hydrolysates and on their peptide fractions.

\section{MATERIAL AND METHODS}

\section{Enzymatic Hydrolysis of Whey Proteins}

Source of whey proteins. Whey protein concentrate (WPC, 35\% proteins) or whey protein isolate (WPI, 94\% proteins) obtained by ionic-exchange chromatography (BiPRO, Davisco Foods International, LeSueur, MN) were used as raw material for the majority of our studies.

Hydrolysis conditions. Trypsin (Type III-S and Type XIII from Sigma, or PTN 6.0S from Novo Nordisk) and chymotrypsin (800S oral grade from Novo Nordisk) were used for the majority of our studies. These two proteases have different substrate specificity. Trypsin cleaves at the C-terminal end of Arg and Lys residues, while chymotrypsin requires an aromatic or bulky nonpolar side chain (Phe, Tyr, Trp, Leu, Met) on the carboxyl side of the scissile bond. For applications in food products such as pasteurized orange juice, a bacterial protease (Enzeco neutral bacterial II, EDC, NY) was also used to hydrolyze WPI, but the specificity of this enzyme preparation was unknown. For all the enzymes, hydrolysis reaction was performed at $\mathrm{pH} 8.0$ and 42 to $45^{\circ} \mathrm{C}$, and the $\mathrm{pH}$-stat technique (Adler-Nissen, 1977) was used to maintain the enzyme preparation at its optimal $\mathrm{pH}$.

Two-step ultrafiltration (UF) process. Figure 1 illustrates the two-step UF process proposed by Turgeon and Gauthier (1990) and later used in many of our studies. The enzymatic hydrolysate was first ultrafiltered using a 30-kDa membrane in order to remove the enzyme and the nonhydrolyzed proteins. The retentate or reaction mixture was discarded whereas the permeate, so-called total hydrolysate (TH), was further fractionated using a $1 \mathrm{kDa}$-membrane, giving a retentate composed of a mixture of polypeptides and a permeate composed of amino acids. These fractions were further characterized and used for evaluation of their functional properties.

\section{Enzymatic hydrolysate}

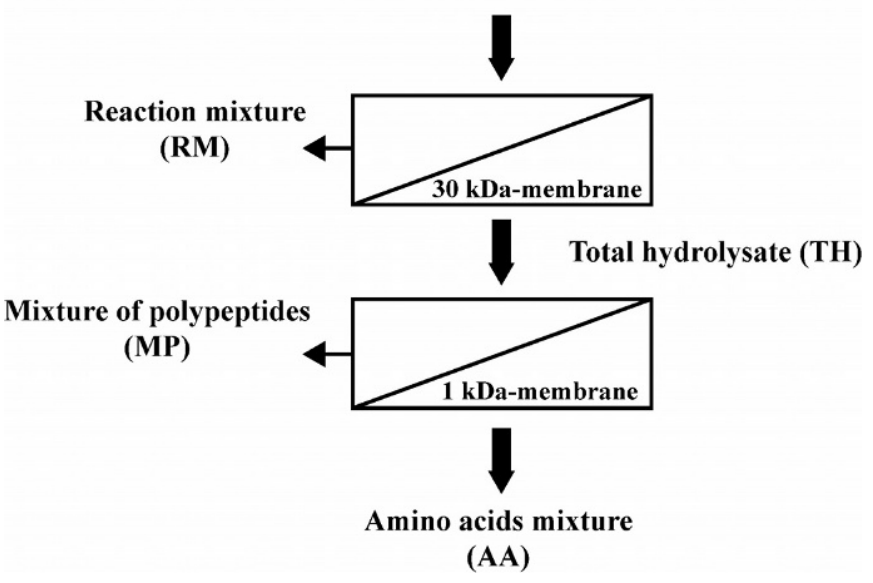

Figure 1. Schematic representation of the two-step ultrafiltration process used for the preparation of enzymatic hydrolysates from whey proteins (Gauthier and Turgeon, 1990).

\section{Peptide Characterization}

Preparation of peptide fractions. Generally, total hydrolysate or mixture of polypeptides were first fractionated by anionic- or cationic-exchange chromatography or by ampholyte-free isoelectric focusing (Rotofor cell, Bio-Rad Laboratories, Hercules, CA) in order to obtain fractions with different peptide composition and properties, and to facilitate the identification of these peptides.

Peptide identification. Peptide fractions prepared as previously described were analyzed by reversedphase HPLC using a C18 column (Nova-Pak, 3.9 i.d. $\times$ $150 \mathrm{~mm}$, Waters, Milford, MA). Elution was performed by applying a linear gradient (0 to 60\%) of a solvent composed of acetonitrile:water:TFA (60:40:0.1\%), and circulating at a flow rate of $1 \mathrm{ml} / \mathrm{min}$. Absorbance was recorded at $214 \mathrm{~nm}$. The main peptidic peaks were collected from RP-HPLC and dried in a Speed-Vac concentrator, then hydrolyzed under vacuum in the presence of $6 \mathrm{~N} \mathrm{HCl}$ for $24 \mathrm{~h}$ at $110^{\circ} \mathrm{C}$ in a Pico-Tag station (Waters). Amino acids were derivatized with phenylisothiocyanate according to the method of Bidlingmeyer et al. (1984), and quantified by RP-HPLC using a PicoTag C18 column. Results from amino acid compositions were used for assignment of peptides in the known sequence of bovine $\beta$-LG and $\alpha$-LA. In some studies (Nadeau, 1995; Barbeau et al., 1996), peptidic peaks collected from RP-HPLC analysis were identified from their mass, as determined by mass spectrometry analysis. 


\section{Functional Properties}

Emulsifying properties. Functional properties of whey peptides were determined in model system designed to reproduce the physicochemical conditions of acidic food systems such as salad dressing. The interfacial properties (Wilhelmy plate method) and emulsion capacity measurements were determined in aqueous solution at $\mathrm{pH} 4.0$ with an ionic strength of 0.6 as described by Turgeon et al. (1992a, 1992b). Emulsifying stability was evaluated in model emulsion representing a salad dressing as proposed by Turgeon et al. (1996). Salad dressing-type emulsion was composed of $62 \%$ corn oil, $32.8 \%$ vinegar, $2.4 \%$ sugar, $1.5 \%$ salt, and $1.3 \%$ spices, and whey peptides were added at level of $1.5 \%$ $(\mathrm{wt} / \mathrm{wt})$. Emulsifying stability during storage $(6 \mathrm{mo}$, $25^{\circ} \mathrm{C}$ ) was also evaluated in liquid concentrated dairybased infant formulas as described by Lajoie et al. (2001). The final composition of model infant formula was $7.2 \%$ carbohydrate, $3.6 \%$ fat, $1.5 \%$ protein $(40 \%$ casein, $60 \%$ whey protein), and $0.25 \%$ minerals. Calcium carrageenan was added $(13.3 \mathrm{mg} / 100 \mathrm{ml})$ as stabilizer or replaced by tryptic hydrolysate or whey peptide fractions $(5 \mathrm{mg} / 100 \mathrm{ml})$.

Denaturation and aggregation properties. The thermal behavior of $\beta$-LG in the presence of WPI tryptic hydrolysate or whey peptides fractions was studied by differential scanning calorimetry analysis at different $\mathrm{pH}$ values (4.6, 5.1, 6.8, 7.5 and 8.0) as described by Barbeau et al. (1996). Thermal aggregation of WPI in the presence of WPI tryptic hydrolysate of whey peptides fractions was evaluated by measuring changes in transmittance at $320 \mathrm{~nm}$ as proposed by Sanchez et al. (1997).

\section{RESULTS AND DISCUSSION}

\section{Peptides Released from Whey Proteins by Trypsin and Chymotrypsin}

Identifying the peptides present in our hydrolysates or peptide fractions has allowed us to better understand the properties of hydrolysates and to ascribe some of these properties to specific sequences. Figure 2 shows the amino acid sequence of $\beta$-LG B and theoretical peptide bonds cleaved by trypsin and chymotrypsin. Table 1 lists the peptides already identified in our studies involving tryptic hydrolysis of whey proteins; some physiochemical characteristics of these peptides are also given. An initial examination of the peptidic sequences found reveals that the majority of the tryptic peptides originated from $\beta$-LG, with only the sequence 105-108 resulting from $\alpha$-LA. This observation is unexpected since about $15 \%$ of this protein is contained in WPI. Also, the number of sequences found originating from
$\beta$-LG is high, given the specificity of trypsin for basic amino acids (Lys, Arg). A total of six nonspecific cleavages $\left(\mathrm{Tyr}_{20}-\mathrm{Ser}_{21}, \mathrm{Met}_{24}-\mathrm{Ala}_{25}, \mathrm{Leu}_{32}\right.$-Asp ${ }_{33}, \mathrm{Phe}_{82}$-Lys 83 , and $\mathrm{Met}_{145}-\mathrm{His}_{146}$ for $\beta$-LG, and Trp ${ }_{104}-\mathrm{Leu}_{105}$ for $\alpha$-LA) were observed for $\beta$-LG or $\alpha$-LA, leading to peptides 15-20, 21-40, 25-40, 33-40, 76-82, 78-82, 83-91, and $146-148$ from $\beta$-LG, and to the sequence $105-108$ from $\alpha$-LA. All of these non-specific cleavage sites correspond to chymotrypsin specificity, which is mainly towards aromatic and hydrophobic amino acids (Phe, Tyr, Trp, Leu, Met), and indicate the presence of chymotrypsin in the commercial trypsin preparations. Also, we observed that the large peptide $\beta$-LG 102-124 (2648 Da) containing one disulfide bridge and the free thiol group $\mathrm{Cys}_{121}$ was not found in any of our tryptic hydrolysates, nor in any other study reported on tryptic hydrolysates of whey proteins, except for the study of Maynard et al. (1998) which found the sequence $\beta$-LG 102-124+ 149-162. Hydrolysis conditions ( $\mathrm{pH} 8.0$ ) may have increased the reactivity of the free thiol group and led to intra- and intermolecular rearrangement, resulting in aggregates retained by UF membrane or difficult to separate by RP-HPLC analysis.

Table 2 presents peptidic sequences identified in chymotryptic hydrolysate of whey proteins, and some of their physicochemical characteristics. For this hydrolysate, all of the peptides originated from $\beta$-LG, and 15 of the 19 sequences identified resulted from at least one tryptic cleavage. This result therefore indicates that the chymotrypsin preparation (800S oral grade, Novo Nordisk) used for the preparation of this hydrolysate was highly contaminated by trypsin. Also, if both specificity of trypsin and chymotrypsin were considered, many more peptides might be identified ( $>35$ theoretical peptides, Figure 2). However, we were not able to detect all sequences probably because some were in too low a concentration or too small for detection at $214 \mathrm{~nm}$. Finally, as for tryptic hydrolysates, the fragment $(\beta$ LG 106-122 or intermediates) containing one disulfide bridge and the free thiol group $\left(\mathrm{Cys}_{121}\right)$ was not identified in the samples.

\section{Functional Properties of Whey Peptides}

Emulsifying peptides from $\beta$-lactoglobulin. Many authors (Turgeon et al., 1992a, 1992b; Gauthier et al., 1993; Mutilangi et al., 1996; Turgeon et al., 1996; Huang e al., 1996; Rahali et al., 2000) have reported that solubility and emulsifying properties of tryptic whey proteins hydrolysates are higher than that of the native proteins. In previous work (Turgeon et al., 1992a), we have demonstrated that the improvement of emulsifying properties could be related to the peptides $\beta$-LG $21-40$ and $41-60$. This latter peptide pos- 


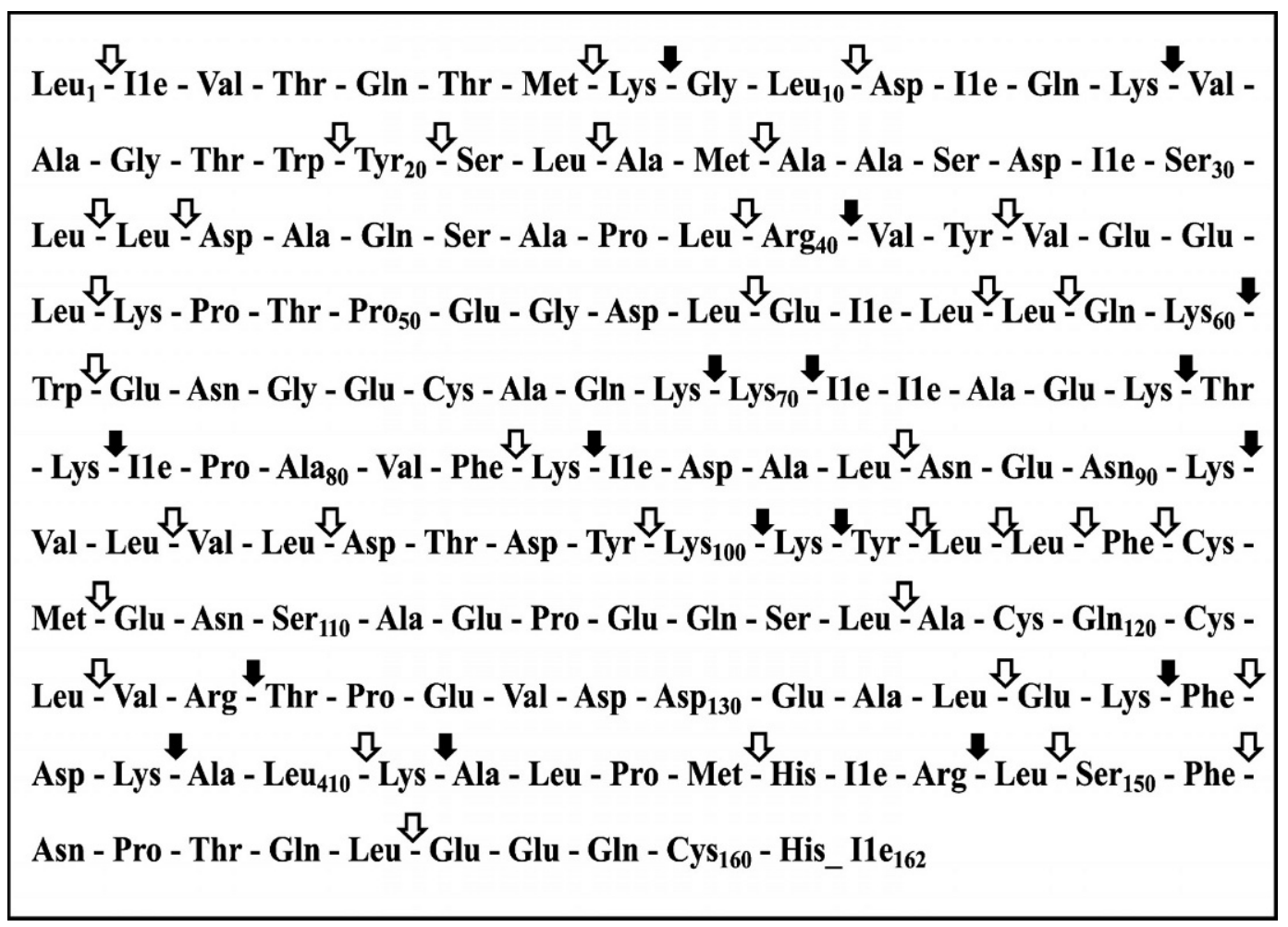

Figure 2. Amino acid sequence of bovine $\beta$-lactoglobluline B showing theoretical peptide bonds cleaved by trypsin ( $\downarrow$ Lys, Arg) and chymotrypsin ( $\Downarrow$ Phe, Tyr, Trp, Met, Leu). Data were from ExPaSy molecular biology server.

sesses a periodic distribution of polar and hydrophobic residues and a minimum molecular weight allowing for its distribution. Rahali et al. (2000) also found that these peptides or shorter fragments ( $\beta$-LG $21-32$ and 41-57) generated from $\beta$-LG by controlled trypsin hydrolysis are surface active peptides at oil-water interface. Finally, a study by Huang et al. (1996) suggested that the emulsifying properties of $\beta$-LG $41-100+149$ 162 were superior to those of $\beta$-LG 41-60 described by Turgeon et al. (1992a). Characterization of this 8.6$\mathrm{kDa}$ oligopeptide suggested that native secondary and tertiary structures would correspond to a five-stranded anti-parallel " $\beta$-barrel" fragment (Chen et al., 1993). Monaco et al. (1987) suggested that the core $\beta$-barrel domain is the hydrophobic region that binds small hydrophobic molecules, such as fatty acids and retinol. Hence, this domain fragment, because of its solubility, amphipolarity, secondary and tertiary structure, and structural flexibility, showed excellent surface activity (Huang et al., 1996).

Stability of salad dressing. To confirm emulsifying properties of peptides from $\beta$-LG, enzymatic hyrolysates of WPC were tested as emulsifiers in vinaigrettes representing a model oil-in-water emulsion (Gauthier et al., 1993; Turgeon et al., 1996). Under these condi- tions, tryptic peptides of $\beta$-LG gave mayonnaise-like textures stable for over 6 mo at room temperature. Chymotryptic peptides had similar emulsification capacity, but the mayonnaise did not show such storage stability.

Improved storage stability of infant formulas. Whey peptides were also tested in liquid concentrated dairy-based infant formula as replacement of carrageenan after their fractionation using either cationic- or anionic-exchange chromatography (Lajoie et al., 2001). The storage stability (fat separation in the product) of the retort-sterilized products added with peptidic fractions $(5 \mathrm{mg} / 100 \mathrm{ml})$ was followed at $25^{\circ} \mathrm{C}$ for up to 6 mo. The peptidic fractions providing the best improvement in the storage stability of model infant formula were obtained from anionic-exchange chromatography and were mainly composed of highly negatively charged peptides (Lajoie et al., 2001). In fact, $35 \%$ of its peptidic content was composed of the negatively charged peptides $\beta$-LG 41-60 (-3), $\beta$-LG 61-69 + 149-162 (-3) and $\beta$-LG 125-135 (-4) identified in the ultrafiltered-tryptic hydrolysate. From this group of negatively charged peptides, we noticed the presence of the peptide $\beta$-LG $41-$ 60 , previously identified by Turgeon et al. (1992a), and a fragment of the $\beta$-barrel domain of $\beta$-LG ( $\beta$-LG $61-$ $69+149-162$ ) already identified by Huang et al. (1996), 
Table 1. Peptidic sequences identified in tryptic hydrolysates of whey proteins and some of their physicochemical characteristics; data from various studies ${ }^{1}$ using different trypsin preparations: Type III-S and Type XIII from Sigma, and PTN 6.0S from Novo Nordisk.

\begin{tabular}{|c|c|c|c|c|c|}
\hline Peptidic sequence & Trypsin used & $\begin{array}{l}\mathrm{MW}^{2} \\
(\mathrm{Da})\end{array}$ & $\mathrm{pI}^{2}$ & $\begin{array}{l}\text { Charge at } \\
\mathrm{pH} 7.0\end{array}$ & $\mathrm{H}_{\phi \mathrm{av}}{ }^{3}$ \\
\hline$\beta$-LG $1-8$ & XIII, PTN & 933 & 8.8 & +1 & 1.34 \\
\hline$\beta$-LG 1-14 & III-S & 1588 & 8.6 & +1 & 1.26 \\
\hline$\beta$-LG 9-14 & XIII, PTN & 673 & 5.8 & 0 & 1.14 \\
\hline$\beta$-LG $15-20^{4}$ & III-S, PTN & 696 & 5.5 & 0 & 1.46 \\
\hline$\beta$-LG $15-40$ & III-S, XIII & 2708 & 4.2 & -1 & 1.14 \\
\hline$\beta$-LG $21-40^{4}$ & III-S, XIII & 2030 & 4.2 & -1 & 1.05 \\
\hline$\beta$-LG $25-40^{4}$ & III-S, PTN & 1628 & 4.2 & -1 & 1.03 \\
\hline$\beta$-LG $33-40^{4}$ & PTN & 857 & 5.8 & 0 & 0.91 \\
\hline$\beta$-LG 41-60 & III-S, XIII, PTN & 2314 & 4.3 & -3 & 1.37 \\
\hline$\beta$-LG $61-69$ & III-S, XIII & 1064 & 4.5 & -1 & 0.69 \\
\hline$\beta$-LG $61-69+149-162^{5}$ & III-S, XIII, PTN & 2703 & 4.5 & -3 & 0.90 \\
\hline$\beta$-LG $61-70$ & III-S, XIII & 1192 & 6.1 & 0 & 0.78 \\
\hline$\beta$-LG $61-70+149-162^{5}$ & III-S, XIII, PTN & 2831 & 4.9 & -2 & 0.93 \\
\hline$\beta$-LG $71-75$ & III-S, XIII, PTN & 573 & 6.0 & 0 & 1.63 \\
\hline$\beta$-LG $76-82^{4}$ & PTN & 775 & 8.4 & +1 & 1.80 \\
\hline$\beta$-LG 76-83 & III-S, XIII & 903 & 10.0 & +2 & 1.76 \\
\hline$\beta$-LG 78-82 & PTN & 546 & 5.5 & 0 & 2.13 \\
\hline$\beta$-LG 78-83 & XIII, PTN & 674 & 8.8 & +1 & 2.03 \\
\hline$\beta$-LG $83-91^{4}$ & PTN & 1044 & 6.1 & 0 & 1.01 \\
\hline$\beta$-LG 84-91 & III-S, XIII, PTN & 916 & 4.4 & -1 & 0.95 \\
\hline$\beta$-LG 92-100 & III-S, XIII & 1065 & 4.2 & -1 & 1.44 \\
\hline$\beta$-LG 92-101 & III-S, XIII & 1193 & 5.9 & 0 & 1.45 \\
\hline$\beta$-LG $125-135$ & III-S, XIII, PTN & 1245 & 3.8 & -4 & 0.85 \\
\hline$\beta$-LG $125-138$ & XIII & 1636 & 4.0 & -4 & 0.97 \\
\hline$\beta$-LG 136-138 & III-S, PTN & 409 & 5.8 & 0 & 1.38 \\
\hline$\beta$-LG 139-141 & III-S, XIII, PTN & 330 & 8.8 & +1 & 1.55 \\
\hline$\beta$-LG $142-148$ & III-S, XIII, PTN & 837 & 9.8 & +1 & 1.54 \\
\hline$\beta$-LG $146-148^{4}$ & PTN & 425 & 9.8 & +1 & 1.23 \\
\hline$\beta$-LG 149-162 & III-S, XIII & 1659 & 4.5 & -2 & 1.03 \\
\hline$\alpha$-LA $105-108^{4}$ & PTN & 468 & 8.8 & +1 & 1.16 \\
\hline
\end{tabular}

\footnotetext{
${ }^{1}$ Turgeon et al., 1992a; Nadeau, 1995; Barbeau et al., 1996; Wijers et al., 1998; Pouliot et al., 1999, 2000; Persaud et al., 2000; Lajoie, 2001.

${ }^{2}$ Theoretical molecular weight (MW) and isoelectric point (pI) were calculated from ExPaSy molecular biology server.

${ }^{3}$ Average hydrophobicity was calculated according to the method of Bigelow (1967).

${ }^{4}$ Peptides obtained from chymotryptic cleavage.

${ }^{5}$ Peptides bonded by a disulfide bridge.
}

both peptidic sequences reported to have high emulsifying properties. Comparatively, the other fractions giving lower performance in terms of storage stability could be related to the absence of the peptide $\beta$-LG 4160 in these fractions. As a consequence of the prevalence of negatively charged peptides in anionic fractions, the isoelectric points of the peptides composing these fractions were in the acidic range $(<6.0)$. The hypothesis proposed for the apparent stabilization of the infant formulas by peptides was that large $(\sim 2 \mathrm{kDa})$ and negatively charged peptides were possibly adsorbed at the fat globules's interface and generated electrostatic repulsions preventing flocculation from destabilizing the colloidal system.

Effect of whey peptides on the denaturation of $\beta$-lactoglobulin. A tryptic hydrolysate of WPI was fractionated by anionic-exchange and RP-HPLC. The denaturation profile using differential scanning calo- rimetry of $\beta$-LG alone and in the presence of the total hydrolysate or peptidic fractions was determined (Barbeau et al., 1996). The nonfractionated hydrolysate was demonstrated to decrease the thermal stability of $\beta$-LG, whereas almost all the peptidic fractions (AEand RP-HPLC) increased denaturation temperature and heat enthalpy. The fractions obtained from anion exchange-HPLC thermally stabilized $\beta$-LG as function of their ionic charge, and this effect became more important as the $\mathrm{pH}$ was raised from 4.6 to 8.0. These observations were explained by the possible binding of peptides to $\beta$-LG, possibly via ionic or hydrophobic interactions that could stabilize $\beta$-LG by increasing the amount of energy required for the unfolding of its structure during heating.

Following these observations, a study of the impact of whey peptides on the thermal aggregation of WPI was performed (Sanchez et al., 1997). Thermal aggrega- 
Table 2. Peptidic sequences identified in chymotryptic hydrolysate ${ }^{1}$ of whey proteins and some of their physicochemical characteristics; data from Pouliot et al. (2000).

\begin{tabular}{|c|c|c|c|c|}
\hline Peptidic sequence & $\begin{array}{l}\mathrm{MW}^{2} \\
(\mathrm{Da})\end{array}$ & $\mathrm{PI}^{2}$ & $\begin{array}{l}\text { Charge at } \\
\mathrm{pH} 7.0\end{array}$ & $\mathrm{H}_{\phi \mathrm{av}}{ }^{3}$ \\
\hline$\beta$-LG $8-14^{4}$ & 801 & 8.6 & +1 & 1.19 \\
\hline$\beta$-LG $15-19^{4}$ & 533 & 5.5 & 0 & 1.18 \\
\hline$\beta$-LG $15-20^{4}$ & 696 & 5.5 & 0 & 1.46 \\
\hline$\beta$-LG 33-39 & 701 & 3.8 & -1 & 0.93 \\
\hline$\beta$-LG $41-42^{4}$ & 280 & 5.5 & 0 & 2.28 \\
\hline$\beta$-LG $41-60^{4}$ & 2314 & 4.3 & -3 & 1.37 \\
\hline$\beta$-LG $70-75^{4}$ & 701 & 8.6 & +1 & 1.61 \\
\hline$\beta$-LG $76-82^{4}$ & 775 & 8.4 & +1 & 1.8 \\
\hline$\beta$-LG $78-82^{4}$ & 546 & 5.5 & 0 & 2.13 \\
\hline$\beta$-LG $84-91^{4}$ & 916 & 4.4 & -1 & 0.95 \\
\hline$\beta$-LG $94-101^{4}$ & 981 & 5.9 & 0 & 1.30 \\
\hline$\beta$-LG 96-99 & 512 & 3.6 & -2 & 0.83 \\
\hline$\beta$-LG $100-103$ & 551 & 9.7 & +2 & 2.06 \\
\hline$\beta$-LG $103-105$ & 392 & 5.5 & 0 & 2.48 \\
\hline$\beta$-LG $125-135^{4}$ & 1245 & 3.8 & -4 & 0.85 \\
\hline$\beta$-LG $125-136^{4}$ & 1393 & 3.8 & -4 & 1.00 \\
\hline$\beta$-LG $125-138^{4}$ & 1636 & 4.0 & $-4-4$ & 0.97 \\
\hline$\beta$-LG $142-145^{4}$ & 431 & 5.6 & 0 & 1.76 \\
\hline$\beta$-LG $146-148^{4}$ & 425 & 9.8 & +1 & 1.23 \\
\hline
\end{tabular}

\footnotetext{
${ }^{1}$ The hydrolysate was prepared with chymotrypsin $800 \mathrm{~S}$ oral grade from Novo Nordisk.

${ }^{2}$ Theoretical molecular weight (MW) and isoelectric point (pI) were calculated from ExPaSy molecular biology server.

${ }^{3}$ Average hydrophobicity was calculated according to the method of Bigelow (1967).

${ }^{4}$ Peptides obtained from tryptic cleavage.
}

tion of WPI at $\mathrm{pH} 6.0$ was improved by adding 20 to $40 \%$ of a peptidic fraction isolated from a tryptic hydrolysate of WPI. Peptide identification revealed that this fraction contained $27 \%$ of $\beta$-LG $21-40$ and $52 \%$ of $\beta$-LG 41-60. However, in these experiments, it was shown that adding peptide fractions induced a $\mathrm{pH}$ drop, which promoted the observed isoelectric precipitation of whey proteins, but this $\mathrm{pH}$-drop could not alone explain the dramatic change in aggregation profile of WPI in the presence of peptidic fractions.

Finally, enzymatic hydrolysis was also used to stabilize WPI against heat treatments when incorporated into acidic beverage (orange juice) for protein fortification (Myrand, 1999). It was found that the hydrolysis of WPI by a bacterial enzyme extract from Bacillus subtilis (Enzeco neutral bacterial II) and followed by a UF-treatment for removing the enzyme could stabilize the juice against heat coagulation during bottle sterilization.

\section{Biological Properties of Whey Peptides}

Literature on the numerous potential physiological functions of whey proteins is now converging towards the concept of bioactive peptides (Clare and Swaisgood, 2000; Smacchi and Gobbetti, 2000). Because the physiological functions of whey proteins are expressed after gastric and intestinal digestive functions, bioactive peptides are likely to be targeted as in situ bioactive mole- cules. The bioactive peptides already found in enzymatic hydrolysates of $\beta$-LG and $\alpha$-LA are listed in Table 3. It is shown that ACE-inhibitory activity is currently among the most documented bioactivity of whey peptides.

Antihypertensive activity of whey proteins hydrolysate. Angiotensin-I converting enzyme cleaves the two N-terminal amino acids of decapeptide angiotensin-I, which is converted into angiotensin-II, a powerful vasoconstrictor. The classical pharmacological approach for the control of hypertension is to use ACEinhibitors in order to control levels of angiotensin-II. Some of our recent work on enzymatic hydrolysis of whey proteins has allowed the preparation of bioactive peptides in mixtures having ACE-inhibitory activity. This work has resulted in the development of Biozate 1 , a new ingredient concept involving enzymatic hydrolysis of WPI obtained by ionic-exchange chromatography (BiPRO, Davisco Foods International, LeSueur, MN). This high-purity hydrolysate has demonstrated significant $(P<0.05)$ antihypertensive properties during the $7 \mathrm{~h}$-period following oral ingestion by spontaneously hypertensive rats at a dosage of $75 \mathrm{mg} / \mathrm{kg}$. The antihypertensive properties of Biozate 1 has also been evaluated in a clinical trial with untreated borderline hypertensive subjects, and the data has shown that Biozate 1 induced significant decreases in both systolic and diastolic blood pressures at a daily dose of $20 \mathrm{~g}$, 
Table 3. Bioactive peptides found in enzymatic hydrolysates of bovine $\beta$-lactoglobulin ( $\beta$-LG) and $\alpha$-lactalbu$\min (\alpha$-LA).

\begin{tabular}{lll}
\hline Peptide & Activity & Reference \\
\hline$\beta$-LG 9-14 & ACE-inhibitory & Pihlanto-Leppälä et al., 1998 \\
$\beta$-LG 15-19 & ACE-inhibitory & Pihlanto-Leppälä et al., 2000 \\
$\beta$-LG 15-20 & ACE-inhibitory & Pihlanto-Leppälä et al., 1998 \\
$\beta$-LG 22-25 & Bactericidal & Pellegrini et al., 2001 \\
$\beta$-LG 25-40 & ACE-inhibitory & Pihlanto-Leppälä et al., 2000 \\
$\beta$-LG 32-40 & Bactericidal & Pellegrini et al., 2001 \\
$\beta$-LG 71-75 & ACE-inhibitory & Pihlanto-Leppälä et al., 2000 \\
$\beta$-LG 78-80 & Hypocholesterolemic & Nagaoka et al., 2001 \\
$\beta$-LG 78-83 & ACE-inhibitory & Abubakar et al., 1998 \\
$\beta$-LG $81-83$ & Bactericidal & Pellegrini et al., 2001 \\
$\beta$-LG 92-100 & ACE-inhibitory & Pihlanto-Leppälä et al., 2000 \\
$\beta$-LG 94-100 & Bactericidal & Pellegrini et al., 2001 \\
$\beta$-LG 102-105 & ACE-inhibitory & Pihlanto-Leppälä et al., 2000 \\
$\beta$-LG 106-111 & Opioid, Muscle contraction & Antila et al., 1991 \\
$\beta$-LG 142-146 & ACE-inhibitory & Mullally et al., 1996 \\
$\beta$-LG 142-148 & ACE-inhibitory & Pihlanto-Leppälä et al., 2000 \\
& ACE-inhibitory & Pihlanto-Leppälä et al., 2000 \\
$\beta$-LG 146-149 & ACE-inhibitory & Mullally et al., 1997 \\
$\alpha$-LA 1-5 & ACE-inhibitory & Mullally et al., 1996 \\
$\alpha$-LA 17-31+109-104 & Muscle contraction & Pihlanto-Leppälä et al., 1997 \\
$\alpha$-LA 61-68+75-80 & Bactericidal & Pellegrini et al., 1999 \\
$\alpha$-LA 50-52 & Bactericidal & Pellegrini et al., 1999 \\
$\alpha$-LA 50-53 & Bactericidal & Pellegrini et al., 1999 \\
$\alpha$-LA 51-53 & ACE-inhibitory & Pihlanto-Leppälä et al., 2000 \\
$\alpha$-LA 99-108 & Opioid & Antila et al., 1991 \\
$\alpha$-LA 104-108 & ACE-inhibitory & Mullally et al., 1996 \\
$\alpha$-LA 105-110 & Immunomodulating & Fiat et al., 1993 \\
\hline & ACE-inhibitory & Pihlanto-Leppälä et al., 2000 \\
& ACE-inhibitory & Pihlanto-Leppälä et al., 2000 \\
& ACE-inhibitory & Pihlanto-Leppälä et al., 1998 \\
\hline & &
\end{tabular}

which persisted throughout the study (Pins and Keenan, 2002).

\section{NF-Fractionation of Whey Protein Hydrolysates}

Nanofiltration was used for the fractionation of whey protein enzymatic hydrolysates in order to further improve their functional and bioactive properties. A study of the effect of $\mathrm{pH}$ and ionic strength on the fractionation of $\beta$-LG tryptic peptides by $\mathrm{NF}$ membranes showed that maximum membrane selectivity was obtained at $\mathrm{pH} 9.0$, while $\mathrm{NaCl}$ addition $(0.5 M)$ increased peptide permeability (Pouliot et al., 1999). These results suggested that the control of peptide charge could increase the selectivity in NF. A comparative study of the NF-fractionation of $\beta$-LG tryptic and chymotryptic peptides (Pouliot et al., 2000) evidenced that the characteristics (mass and charge) of peptides in a mixture had an important impact on the selectivity of separation. This work showed that the separation of charged fragments in tryptic peptide mixtures was better than those in chymotryptic peptide mixtures. It was hypothesized that since chymotrypsin generates a broader range of peptide characteristics (mass, charge), the fractionation more likely to be hindered by peptide/peptide interactions and therefore will in turn affect the separation of charged peptides. Recent data (Lapointe et al., 2003) showed important changes in NF selectivity as affected by hydrodynamic conditions and recirculation time, via possible peptide/peptide interactions occurring in the concentration polarization layer at the vicinity of membrane surface. Following these results, additional work was performed to better understand those peptide/peptide and peptide/protein interactions in order to improve the selectivity during NF fractionation of peptide mixtures.

\section{Studying Interactions of Whey Peptides}

Interactions between whey peptides and $\beta-L G$. A simple methodological approach has recently been proposed for the study of peptide/ $\beta$-LG interactions (Noiseux et al., 2002). As illustrated in Figure 3, $\beta$-LG and peptide solutions were mixed in an Eppendorf tube and incubated under different physicochemical conditions: $\mathrm{pH} 3,6.8$ and $8.0 ; 4,25$, and $40^{\circ} \mathrm{C}$, buffer molarity of 0.05 and $0.1 M$; ratio $\beta$-LG:peptide of $1: 5$ and $1: 10$. After overnight incubation, solutions were transferred to a centrifugal filter device (Microcon YM-10 kDa), and centrifuged at $9500 \times \mathrm{g}$ for 35 to $45 \mathrm{~min}$. Filtrates containing unbound peptides were then analyzed by RP-HPLC in order to quantify their amount, and to 
12 h-reaction under specific physicochemical conditions

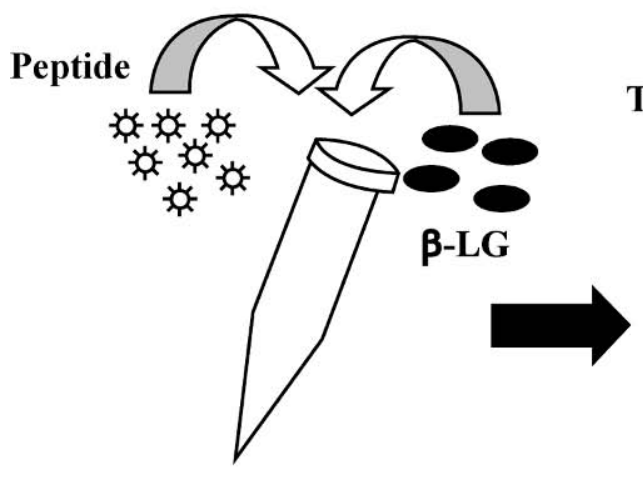
Transfer into centrifugal filter device (10kDa)

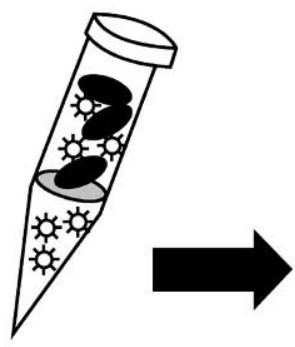

\section{RP-HPLC analysis of unbound peptide}

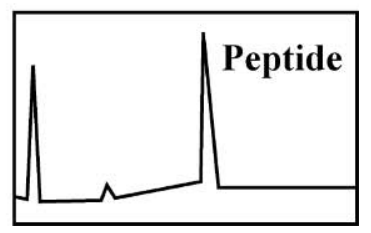

Figure 3. Schematic representation of the procedure used to study peptide/ $\beta$-lactoglobulin interactions (Noiseux et al., 2002).

estimate the quantity of peptides bound to the protein. Using this method, it has been observed that almost no peptide/ $\beta$-LG interactions occurred at acidic $\mathrm{pH}$ (3.0), probably because $\beta$-LG and all of the peptides under study ( $\beta$-LG $125-135,130-135,69-83,146-149)$ were positively charged, making interactions between these molecules difficult due to electrostatic repulsion. However, at $\mathrm{pH} 6.8$ and 8.0 peptides interact with $\beta$-LG at different extent depending upon the nature of the peptide and the physicochemical conditions of the media (mainly ionic strength and temperature). We also observed that hydrophobic peptides such as $\beta$-LG 102105 probably bind to the inner cavity of $\beta$-LG, leading to the release of material absorbing at $214 \mathrm{~nm}$. Such data therefore suggests that $\beta$-LG would be used as a carrier for bioactive peptides (e.g., $\beta$-LG $102-105$ is an opioid peptide). Also, the occurrence of such interactions may explain earlier observations on the effect of peptide-induced changes of $\beta$-LG unfolding during heat treatment (Barbeau et al., 1996). More work will, however, be needed to characterize the material released at $214 \mathrm{~nm}$, and to evaluate the effect of peptide binding on certain structural properties and thermal behaviour of $\beta$-LG.

Peptide/peptide interactions studied by IEF. Isoelectric focusing (IEF) was used for the identification of peptide-peptide interactions in a tryptic hydrolysate of $\beta$-LG (Groleau et al., 2002). Hydrolysate solutions were fractionated by ampholyte-free liquid-phase IEF on a preparative Rotofor cell. The 20 peptidic fractions collected from the cells were analyzed by capillary elec- trophoresis and SDS-PAGE under native, denaturing and reducing conditions. An important proportion (62\%) of the peptidic material was found in the acidic region ( $\mathrm{pH} 2$ to 5) of the cell, as expected from their $\mathrm{pI}$ value. Purified peptides ( $\beta$-LG 15-20, 71-75, 76-82, and 84-91) were also focused individually and in mixture, and further identified in the IEF-fractions. The results showed that IEF could achieve the separation between acidic and basic peptides while uncharged peptides were poorly separated due to their low electrophoretic mobility. From this study it was difficult to ascertain the occurrence of peptide interactions. However, it was noticed that peptides $\beta$-LG $15-20$ and $\beta$-LG 7175 were concentrated in the fractions at $\mathrm{pH} 7.5-8.5$, which was a higher $\mathrm{pH}$ value compared to their $\mathrm{pI}$ of 5.5 and 6.0, respectively. This unexpected behavior of both peptides thus could reflect some peptide/peptide interactions.

Peptidelpeptide interactions leading to aggregation. The IEF-fractionation of tryptic peptides from $\beta$-LG (Groleau et al., 2002) evidenced a pH-induced precipitation phenomenon of peptides at acidic values (4.0 to 4.5 ). We therefore tried to characterize the changes in peptide solubility as affected by some physicochemical conditions (Groleau et al., 2003). The turbidity of a $1 \%(\mathrm{wt} / \mathrm{vol}$ ) solution of tryptic peptides from $\beta$-LG was measured at $500 \mathrm{~nm}$ under different physicochemical conditions: temperature of 5,25 , and $50^{\circ} \mathrm{C}$; pH 3 to 10; in the presence of different salt concentrations $(0,0.5$, and $1 \mathrm{M} \mathrm{NaCl})$, denaturing and reducing agents (6 $M$ urea, $5 \%$ SDS or $5 \% \beta$-mercaptoethanol). 
Results confirmed an increase of turbidity of the solution at $\mathrm{pH}$ 4. The temperature and ionic strength dependency of the turbidity occurring at $\mathrm{pH} 4$ indicated that hydrophobic interactions were involved in the aggregation process. The precipitate at $\mathrm{pH} 4$ was collected and analyzed by mass spectrometry, and the peptides were identified as $\beta$-LG 15-20, 41-60, 1-8, and large hydrophobic peptides containing disulfide bridges. This data strengthens the hypothesis that both electrostatic and hydrophobic interactions do occur in a mixture of tryptic peptides from $\beta$-LG, and that these interactions may have a strong negative impact on the fractionation of these peptides by membrane processes.

\section{CONCLUSIONS}

The results summarized in this paper illustrate the high potential of whey peptides for use in food or biological systems. The functional properties of whey protein enzymatic hydrolysates mainly originate from $\beta$-LG peptides. Peptide sequence $\beta$-LG $41-60$ and to a lesser extent peptides $\beta$-LG $21-40$ and $61-69+149-162$ were involved in the stabilization of emulsions, in thermal stabilization of $\beta$-LG or in peptide-peptide interactions. It was also demonstrated that fractionation of peptides on the basis of their charge, e.g., by anionic- or cationicexchange chromatography, produced fractions having improved properties. These observations suggest that electrostatic interactions between charged peptides could have a negative effect both on the properties of whey protein hydrolysates and on their NF-fractionation. It also appears that the interaction potential of whey peptides is related to the distribution of charge and hydrophobic residues in their sequence. In addition to peptide fractionation, the control of peptide interactions can therefore be achieved by manipulating $\mathrm{pH}$, ionic strength, and temperature of their environment.

Our observations on the interactions occurring between $\beta$-LG and some peptides have helped to explain the effects of whey peptides in complex systems. However, beyond these effects, the elucidation of $\beta$-LG/peptides interactions may lead to a better exploitation of bioactive properties of whey peptides and to an understanding of some physiological functions of $\beta$-LG.

\section{ACKNOWLEDGMENTS}

These studies were supported by grants from the Natural Sciences and Engineering Research Council (NSERC), and Fonds pour la Formation de Chercheurs et l'Aide à la Recherche (FCAR), Novalait Inc., Ministère de l'Agriculture, des Pêcheries et de l'Alimentation du Québec (MAPAQ).

\section{REFERENCES}

Abubakar, A., T. Saito, H. Kitazawa, Y. Kawai and T. Itoh. 1998. Structural analysis of new antihypertensive peptides derived from cheese whey protein by proteinase K digestion. J. Dairy Sci. 81:3131-3138.

Adler-Nissen, J. 1977. Enzymatic hydrolysis of food proteins. Process Biochem. 12:18-24.

Althouse, P. J., P. Dinakar, and A. Kilara. 1995. Screening of proteolytic enzymes to enhance foaming of whey protein isolates. J. Food Sci. 60:1110-1112.

Antila, P., I. Paakkari, A. Järvinen, M. J. Mattila, M. Laukkanen, A. Pihlanto-Leppälä, P. Mäntsälä, and J. Hellman. 1991. Opioid peptides derived from in-vitro proteolysis of bovine whey proteins. Int. Dairy J. 1:215-229.

Barbeau, J., S. F. Gauthier, and Y. Pouliot. 1996. Thermal stabilization of $\beta$-lactoglobulin by whey peptide fractions. J. Agric. Food Chem. 44:3939-3945.

Bidlingmeyer, B. A., S. A. Cohen, and T. L. Tarvin. 1984. Rapid analysis of amino acids using pre-column derivatization. J. Chromatogr. 336:93-104.

Bigelow, C. 1967. On the average hydrophobicity of proteins and the relation between it and protein structure. J. Theor. Biol. $16: 187-211$.

Chen, S. X., C. C. Harding, and H. E. Swaisgood. 1993. Purification and characterization of $\beta$-structural domains of $\beta$-lactoglobulin liberated by limited proteolysis. J. Protein Chem. 12:613-625.

Chen, S. X., H. E. Swaisgood, and E. A. Foegeding. 1994. Gelation of $\beta$-lactoglobulin treated with limited proteolysis by immobilized trypsin. J. Agric. Food Chem. 42:234-239.

Clare, D. A., and H. E. Swaisgood. 2000. Bioactive milk peptides: a prospectus. J. Dairy Sci. 83:1187-1195.

Euston, S. R., S. R. Finnigan, and R. L. Hirst. 2001. Heat-induced destabilization of oil-in-water emulsion formed from hydrolyzed whey protein. J. Agric. Food Chem. 49:5576-5583.

Fiat, A.-M., D. Miglore-Samour, P. Jollès, L. Drouet, C. Bal dit Sollier, and J. Caen. 1993. Biologically active peptides from milk proteins with emphasis on two examples concerning antithrombic and immunomodulating activities. J. Dairy Sci. 76:301-310.

Gauthier, S. F., P. Paquin, Y. Pouliot, and S. Turgeon. 1993. Surface activity and related functional properties of peptides obtained from whey proteins. J. Dairy Sci. 76:321-328.

Groleau, P. E., R. Jimenez-Florez, S. F. Gauthier, and Y. Pouliot. 2002. Fractionation of $\beta$-lactoglobulin tryptic peptides by ampholyte-free isoelectric focusing. J. Agric. Food Chem. 50:578-583.

Groleau, P. E., R. Jimenez-Florez, S. F. Gauthier, and Y. Pouliot. 2002. Effect of physicochemical conditions on peptide-peptide interactions in a tryptic hydrolysate of $\beta$-lactoglobulin and identification of aggregating peptides. J. Agric. Food Chem. (accepted). [Au: has this paper been published? Can you provide vol and page nos.?]

Huang, X. L., G. L. Catignani, and H. E. Swaisgood. 1996. Improved emulsifying properties of $\beta$-barrel domain peptides obtained by membrane-fractionation of a limited tryptic hydrolysate of $\beta$-lactoglobulin. J. Agric. Food Chem. 44:3437-3443.

Lajoie, N., S. F. Gauthier, and Y. Pouliot. 2001. Improved storage stability of model infant formula by whey peptides fractions. J. Agric. Food Chem. 49:1999-2007.

Lapointe, J. F., S. F. Gauthier, Y. Pouliot, and C. Bouchard. 2003. Effect of hydrodynamic conditions on fractionation of $\beta$-lactoglobulin tryptic peptides using nanofiltration membranes. J. Memb. Sci. 212:55-67.

Lieske, B., and G. Konrad. 1996. Physico-chemical and functionnal properties of whey protein as affected by limited papain proteolysis and selective ultrafiltration. Int. Dairy J. 6:13-31.

Maynard, F., A. Weingard, J. Hau, and R. Jost. 1998. Effect of highpressure treatment on the tryptic hydrolysis of bovine $\beta$-lactoglobulin AB. Int. Dairy J. 8:125-133.

Monaco, H. L., G. Zanotti, P. Spadon, M. Bolognesi, L. Sawyer, and E. E. Eliopoulos. 1987. Crystal structure of the trigonal form of bovine $\beta$-lactoglobulin and of its complex with retinol at $2.5 \mathrm{~A}$ resolution. J. Mol. Biol. 197:695-706. 
Mullally, M. M., H. Meisel, and R. J. FitzGerald. 1996. Synthetic peptides corresponding to $\alpha$-lactalbumin and $\beta$-lactoglobulin sequences with angiotensin-I-converting enzyme inhibitory activity. Biol. Chem. Hoppe-Seyler 377:259-260.

Mullally, M. M., H. Meisel, and R. J. FitzGerald. 1997. Identification of a novel angiotensin-I-converting enzyme inhibitory peptide corresponding to a tryptic fragment of bovine $\beta$-lactoglobulin. FEBS Lett. 402:99-101.

Mutilangi, W. A. M., D. Panyam, and A. Kilara. 1996. Functional properties of hydrolysates from proteolysis of heat-denatured whey protein isolate. J. Food Sci. 61:270-274, 303.

Myrand, S. 1999. Amélioration des propriétés physico-chimiques et organoleptiques d'hydrolysats enzymatiques de protéines du lactosérum destinés à la fortification protéique d'un jus d'orange. M.Sc. Thesis, Université Laval, Québec.

Nadeau, L. 1995. Hydrolyse trypsique de la $\beta$-lactoglobuline adsorbée à la surface de matrices hydrophobes. M.Sc. Thesis, Université Laval, Québec.

Nagaoka, S., Y. Futamura, K. Miwa, T. Awano, K. Yamauchi, Y. Kanamaru, K. Tadashi, and T. Kuwata. 2001. Identification of novel hypocholesterolemic peptides derived from bovine milk $\beta$ lactoglobulin. Biochem. Biochys. Res. Commun. 281:11-17.

Noiseux, I., S. F. Gauthier, and S. L. Turgeon. 2002. Interactions between bovine $\beta$-lactoglobulin and peptides under different physicochemical conditions. J. Agric. Food Chem. 50:1587-1592.

Panyam, D., and A. Kilara. 1996. Enhancing the functionality of food proteins by enzymatic modification. Trends Food Sci. Technol. $7: 120-125$.

Pellegrini, A., C. Dettling, U. Thomas, and P. Hunziker. 2001. Isolation and characterization of four bactericidal domains in the bovine $\beta$-lactoglobulin. B B A (Biochim. Biophys. Acta) Libr. 1526:131-140.

Pellegrini, A., U. Thomas, N. Bramaz, P. Hunziker and R. von Fellenberg. 1999. Isolation and identification of three bactericidal domains in the bovine $\alpha$-lactalbumin molecule. Biochim. Biophys. Acta 1426:439-448.

Persaud, D. R., D. G. Dalgleish, L. Nadeau, and S. Gauthier. 2000. Isolation and purification of serum and interfacial peptides of a trypsinolyzed $\beta$-lactoglobulin oil-in-water emulsion. J. Chromatogr. B 744:389-397.

Pihlanto-Leppälä, A., P. Koskinen, K. Piilola, T. Tupasela, and H. Korhonen. 2000. Angiotensin I-converting enzyme inhibitory properties of whey protein digests: Concentration and characterization of active peptides. J. Dairy Res. 67:53-64.

Pihlanto-Leppälä, A., I. Paakkari, M. Rinta-Koski, and P. Antila. 1997. Bioactive peptide derived from in vitro proteolysis of bovine $\beta$-lactoglobulin and its effect on smooth muscle. J. Dairy Res. 64:149-155.
Pihlanto-Leppälä, A., T. Rokka, and H. Korhonen. 1998. Angiotensin I converting enzyme inhibitory peptides derived from bovine milk proteins. Int. Dairy J. 8:325-331.

Pins, J. J., and J. M. Keenan. 2002. The antihypertensive effects of a hydrolyzed whey protein isolate supplement (BioZate 1). Cardiovasc. Drugs Ther. 16(Suppl. 1):68. (Abstr.)

Pouliot, Y., S. F. Gauthier, and J. L'Heureux. 2000. Effect of peptide distribution on the fractionation of whey protein hydrolysates by nanofiltration membranes. Lait 80:113-122.

Pouliot, Y., M. C. Wijers, S. F. Gauthier, and L. Nadeau. 1999. Fractionation of whey protein hydrolysates using charged UF/NF membranes. J. Memb. Sci. 158:105-114.

Rahali, V., J. M. Chobert, T. Haertlé, and J. Guéguen. 2000. Emulsification of chemical and enzymatic hydrolysates of $\beta$-lactoglobulin characterization of the peptides adsorbed at the interface. Narhung 44:89-95.

Rahali, V., and J. Guéguen. 2000. Foaming characteristics of chemical and enzymatic hydrolysates of bovine $\beta$-lactoglobulin. Narhung 44:309-317.

Sanchez, C., M. Pouliot, S. F. Gauthier, and P. Paquin. 1997. Thermal aggregation of whey protein isolate containing microparticulated or hydrolyzed whey proteins. J. Agric. Food Chem. 45:2384-2392.

Singh, A. M., and D. G. Dalgleish. 1998. The emulsifying properties of hydrolysates of whey proteins. J. Dairy Sci. 81:918-924.

Smacchi, E., and M. Gobbetti. 2000. Bioactive peptides in dairy products: Synthesis and interaction with proteolytic enzymes. Food Microbiol. 17:129-141.

Turgeon, S. L., and S. F. Gauthier. 1990. Whey peptide fractions obtained with a two-step ultrafiltration process: production and characterization. J. Food Sci. 55:106-110, 157.

Turgeon, S. L., S. F. Gauthier, D. Mollé, and J. Léonil. 1992a. Interfacial properties of tryptic peptides of $\beta$-lactoglobulin. J. Agric. Food Chem. 40:669-675.

Turgeon, S. L., S. F. Gauthier, and P. Paquin. 1992b. Emulsifying property of whey peptide fractions as a function of $\mathrm{pH}$ and ionic strength. J. Food Sci. 57:601-604, 634.

Turgeon, S. L., C. Sanchez, S. F. Gauthier, and P. Paquin. 1996. Stability and rheological properties of salad dressing containing peptidic fractions of whey proteins. Int. Dairy J. 6:645-658.

van der Ven, C., H. Gruppen, D. B. A. de Bont, and A. G. J. Voragen. 2001. Emulsion properties of casein and whey protein hydrolysates and the relation with other hydrolysate characteristics. J. Agric. Food Chem. 49:5005-5012.

van der Ven, C., H. Gruppen, D. B. A. de Bont, and A. G. J. Voragen. 2002. Correlations between biochemical characteristics and foamforming and -stabilizing ability of whey and casein hydrolysates. J. Agric. Food Chem. 50:2938-2946.

Wijers, M. C., Y. Pouliot, S. F. Gauthier, M. Pouliot, and L. Nadeau. 1998. Use of nanofiltration for the desalting of peptide fractions from whey proein enzymatic hydrolysates. Lait 78:621-632. 